\title{
Morphological instances of veri in old (Daco-)Romanian
}

\author{
Andreea Dinică* \\ "Iorgu Iordan - Al. Rosetti" Institute of Linguistics, 13 Calea 13 Septembrie, 050711 Bucharest, Romania
}

\begin{abstract}
Article info
History:

Received June 27, 2017

Accepted July 22, 2017

Published September 30, 2017

Key words:

grammaticalization

predicative verb

auxiliary verb

disjunctive connector

concessive connector

Abstract

In old Romanian, veri < lat. velis has various morphological values-predicative $\operatorname{verb}$ (veri is, etymologically, the $2^{\text {nd }}$ person singular of the verb a vrea 'to want'), future auxiliary (veri face 'you will do'), conjunction or part of a disjunctive conjunction (veri ... veri 'either ... or'), concessive conjunction (să veri că 'although'), component of indefinite pronouns (vericine 'whoever', vericit 'no matter how much', etc.). The formal evolution from the predicative value is the result of a grammaticalization process identified both in Romanian (where it continues a process started in Late Latin) and in other languages, genealogically unrelated, from which Albanian is suggestive for comparison. The purpose of this article is to make an inventory of the formal-functional occurrences of veri, widely attested in old Romanian.
\end{abstract}

\section{Preliminaries}

Veri belongs to the paradigm of the verb a vrea 'to want' (voi(u), veri/vei, va, vrem (i)/văm(u)/vom(u), vreți/veți, vor(u)), a verb ${ }^{1}$ that initially had a unique present indicative paradigm, both as a predicative verb and as an auxiliary. This form comes from Late Latinvelis, the second person subjunctive, that replaces the Classical Latin vis. Veri represents the most archaic form of the evolution of Lat. velis in Romanian. Afterwards, the phonetic evolution of veri takes two different paths, according to the direction of grammaticalization: veri becomes vei (used in present-day Romanian), which occurs as an auxiliary, whereas, as an indefinite marker, veri- evolves into ori-. The different outcomes indicate different grammaticalization processes, which started in Latin (Ernout \& Meillet, 1959, s.v. quis) and were also encountered in Balkan languages (Sandfeld, 1930), as the result of wider typological tendency (Haspelmath, 1997). It must be underlined that, from the earliest Romanian texts, both the archaic veri and the subsequent vei and ori- co-occur, the ratio between the forms varying according to the historical moment the text was issued, the geographical area the text belongs to, and to the stylistic type of text.

\section{The morphological variants of veri}

Within the oldest Romanian texts, veri occurs as predicative (\$2.1), auxiliary (\$2.2), connector $(\$ 2.3)$ either disjunctive (\$2.3.1) or an element from the structure of a concessive connector (\$2.3.2) -, and as an indefinite marker $(\$ 2.4)$.

Further on, we will depict the occurences of the archaic form veri, without discussing the later outcomes vei and ori-.

\subsection{Predicative verb}

Predicative veri is the archaic second person singular from the paradigm of the verb a vrea 'to want' and is attested from the earliest texts. It can occur in independent interrogative contexts (1a), in negative contexts (1b), in main clauses (1c), in different types of subordinates, mainly conditionals (1d-g), but other types as well $(1 \mathrm{~h}-\mathrm{i})$ :

\footnotetext{
*Email address: andreea.dinica@gmail.com.

${ }^{1}$ From the paradigm of a vrea 'want', the $3^{\text {rd }}$ person singular $v a$ also occurs in various morphological variants (see Zamfir \& Dinică, 2009).
} 
(1) a. El grăi ei: „Ce veri?” he said her what want.PREs.2sG

'He said to her: «What do you want?»'

b. $\mathrm{Nu}$ veri să răspunzi nemică ce not want.PREs.2sG S $\breve{A}_{\text {SUBJ }}$ answer.sUBJ.2sG nothing what acești pre tine mărturisesc? $\left(\mathrm{CC}^{2} .1581,97\right)$ these.M.PL DOM you.ACC declare 'Don't you want to answer anything to what they declare about you?'

c. Deci tu însuți nu asculți rugăciunea ta, ome, iară so you yourself NEG listen prayer.DEF your man and Dumnezeu tu veri să $\mathrm{o}$ auză. $\left(\mathrm{CC}^{2} .1581,327\right)$ God you want.PREs.2SG S $\breve{A}_{\text {SUBJ }}$ CL.F.ACC hear.SUBJ.3sG 'You don't listen to your own prayer, man, but you want God do hear it.'

d. Să veri să mergi în viiață, if want.2sG s. $\breve{A}_{\text {SUBJ }}$ walk.SUBJ.2SG in life păzeaște porîncitele $\quad\left(\mathrm{CC}^{2} .1581,288\right)$ watch.IMP.2sG commandment.DEF.PL 'If you want to go in life, obey the commandments.'

e. Să veri desfîrșit să fii, și if want.2SG perfect $\breve{S}_{\text {SUBJ }}$ be.SUBJ.2SG go.IMP.2SG=CL.REFL.2SG and vinde avuțiia ta şi dă mişeilor $\left(\mathrm{CC}^{2} .1581,288\right)$ sell.IMP.2sG fortune your and give.IMP.2SG poor.DEF.PL.DAT 'If you want to be faultless, go and sell your wealth and donate to the poor.'

f. Doamne, să veri, poți să mă

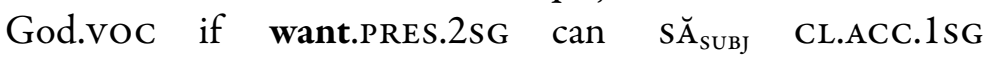
curățești (CT.1560-1,47)

cleanse.SUBJ.2sG

'God, if thou wilst, thou can cleanse me.'

g. Derept aceaia de veri să mă grăiești for that if want.PREs.2SG S $\breve{A}_{\text {SUBJ }}$ CL.ACC.1SG whisper.SUBJ.2SG dulce, ca Dumnezeu mă grăiaşte dulce, $\left(\mathrm{CC}^{2} .1581,433\right)$ gently like God CL.ACC.1sG whisper gently 'Therefore, if you want to call me gentle, you must call me gentle as a God.'

h. Că cît veri, tu faci, și al tău cuvînt lucru that how want.PREs.2SG you do and $\mathrm{AL}_{\mathrm{GEN}}$ your word thing fi-va, și cuvîntului lucrul ajută. $\left(\mathrm{CC}^{2} .1581,227\right)$ be.INF.3SG=AUX.FUT.3sG and word.DEF.DAT thing.DEF helps 'As much as you want to do, you do, and your word shall be a real thing and the real thing enhances the word.'

i. fie ție cum veri $\left(\mathrm{CC}^{2} .1581,326\right)$ be.SUBJ.3SG you.DAT as wish.PRES.2SG 'May you have it as you wish.'

Isolatedly, Zamfir (2005, p. 60) registers veri as an imperative in Psaltirea Scheiană (2a), based on the comparison with other versions of the Psalter (2b):
a. Voia rostului
mieu dulce
veri
Doamne,
will word.gen my
sweet
wish.IMP.2SG
God.voc
şi giudecatelor
tale învață-me
(ps.1573-8, 409)
and judgement.DAT.PL your teach.IMP.2SG $=\mathrm{me}$ 
'God, be propitious to the wish my lips express, and teach me to submit to thy judgement.'

b. Voia rro<stu>lui mieu iubeaște, Doamne, will word.gen my love.IMP.2sG God.voc

$\begin{array}{llll}\text { și dziselor tale învață-me } & (\text { PH.1500-10,106 }\end{array}$

and wisdom.DAT.PL your teach.IMP.2SG=me

'God, be propitious to the wish my lips express, and teach me how to follow thy words.'

\subsection{Auxiliary}

In old Romanian, the present indicative forms of the paradigm a vrea were used both as a predicative verb as well as an auxiliary. Veri occurs as a future auxiliary (3), in anteposition (3a,b) or in postposition ( $3 c-e)$ to the lexical verb, and participates to the future periphrasis of the type voi + subjunctive $(4 a-c)$ :

(3) a. Cîndu veri veni cătră mine? (Ps.1573-8,323) when AUX.FUT.2sG come towards me 'When will thou come towards me?'

b. se venci căndu veri giudeca (PS.1573-8, 159) S $\breve{A}_{\text {SUBJ }}$ vanquish.SUBJ.2sG when AUX.FUT.2sG judge 'that thou shalt judge as a conqueror'

c. Chiamă-mă în dzi de grija ta și call.IMP.2SG=CL.ACC.1SG in day of care your and izbăvi-te-voiu şi save.INF $=$ CL.ACC. $2 \mathrm{SG}=\mathrm{AUX} . \mathrm{FUT} .1 \mathrm{SG}$ and proslevi-me-veri beloud.INF $=$ CL.ACC.1sG $=$ AUX.FUT.2sG

'Call me in the days of your misfortune and I will relieve you and you will glorify me.'

d. Învățătoare, vrea-veri de ce te teacher.VOC wish.INF=AUX.FUT.2sG of what CL.ACC.2SG vrem ceare să faci noao? (СТ.1560-1, 139 $)$ AUX.FUT.PL ask.INF S $\breve{A}_{\text {SUB }}$ do.SUBJ.2sG us 'Master, wilst thou be willing to do what we will ask from you?'

e. Închina-te-veri Domnului Dumnezeul tău worship.INF $=$ CL.ACC.2SG $=$ AUX.FUT.2sG God.DEF.DAT God.DEF your și aceluia unuia sluji-veri $\left(\right.$ Ст.1560-1, 120 $\left.{ }^{\mathrm{r}}\right)$ and that.DAT one.DAT serve.INF=AUX.FUT.2sG

'You will worship your God and you will serve that one.'

(4) a. veri să dai samă înaintea Domnului (șT.1652, 189) AUX.FUT.2SG S $\breve{A}_{\text {SUBJ }}$ answer.SUBJ.2SG before God.DEf.GEN 'you will answer for it before God'

b. tu însuţi ești aicea venit și veri you yourself are here come.pple and AUX.FUT.2sG

să biruiești (PO.1582, 60)

S $\breve{A}_{\text {SUBJ }} \quad$ win.SUBJ.2SG

'you are here yourself and you will win'

c. Și veri să facem trei cămări, ție and want/AUX.FUT.2SG S $\breve{A}_{\text {SUBJ }}$ build.sUBJ.1PL three huts you.DAT

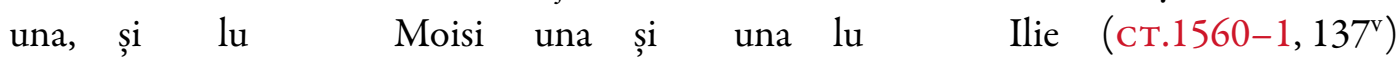
one and LUI.Gen Moses one and one LUI.GEN Elijah 'Wilst thou that we do build here three huts, one for thee, and for Moses one, and for Elijah one' 
The value of veri in the examples under (4) is ambiguous. Due to the strong volitive meaning, it is difficult to establish if it is the predicative verb in one of the hypostases within the process of grammaticalization or it is an already grammaticalized form. The first hypothesis is more acceptable if we admit that the future structure $o$ săfac is based on the type voi + subjunctive (Zamfir, 2007, p. 225).

Regarding the lifetime of both predicative and auxiliary veri and their regional distribution, Zamfir (2005, p. 61-65) distinguishes in the first half of the $17^{\text {th }}$ century, based on a thorough statistical analysis, two distinct dialectal areas-the etymological veri was still used in Moldavia, while in south-west Transylvania vei was already general. For the second half of the $17^{\text {th }}$ century, the use of veri is dramatically reduced in all the regions

\subsection{Connective}

As a connective, veri occurs as a disjunctive conjunction (\$2.3.1) in correlative structures, or as an element within the structure of a concessive connector (\$2.3.2).

\subsubsection{Disjunctive connective}

The inventory of disjunctive connectives in correlative structures in old Daco-Romanian is richer than in the present-day language. Besides the structures that contain connectives encountered in contemporary Romanian (sau ... sau, fie ... fie, ori ... ori), within the whole period there can be found other connectives as well, with different frequency rates, but identical distribution: au ... au, oare ... oare, vare ... vare, veri ... veri, săva(i) ... săva(i) 'either ... or' (Densusianu, 1997, p. 620-621; Frâncu, 2009, p. 148; Croitor, 2016, p. 449-450) (6a-c).

The structures containing disjunctive correlatives usually occur in law codices, mainly in syntactic patterns that imply the naming of a generic type and then enumeration of the set of possibilities:

(5) acela se va certa $\ldots$ de-ar fi orice feliu

that shall AUX.FUT.3sg punish.INF if=would be any kind

de om, ver fie mirean, veri călugăr,

of man either be.subj layman or monk

ver fiece om in clirosul besearecii (Prav.1652, 139)

or any man in staff.DEF church.DEF.GEN

'that one will be punished ... be him any kind of man, either layman, or monk, or any kind of man in the staff of the church'

A specific feature of these patterns with correlative disjunction in old Daco-Romanian is the variation of the connective within the same sentence:

(6) a. să strîngă pă toți rumânii de la sat... oricarii pă unde

to gather DOM all bondsmen from village anyone wherever

să vor afla fugiți... ori în sat

CL.REFL.ACC.3PL AUX.FUT.3PL be.INF gone.PPLE either in village

domnescu, veri în sat boierescu, au în călugărescu,

lordly or in village manorial or in monastic

au la slobozii, veri la tîrguri (DRH,B.1635, 110)

or at free villages or at towns

'to gather all the bondsmen in the village ... anyone wherever is gone ... either in a lordly

village, or in a manorial village, or in a monastic village, or in a free village, or in a town'

b. se vr-un frate numeaște-se vare curvariu,

if any brother call.PRES.3SG=CL.REFL.ACC.3sG either fornicator

vare hasnă-luotoriu, sau drăceaște slujitoriu sau pîrî

or usurer or devilishly servant or denunciation 
uritoriu [...] cu aceia se nu mîncați (Св.1559-60,391-2)

spiteful with those S $\breve{S}_{\text {SUBJ }}$ NEG eat.SUBJ.1PL

'if a brother of yours is either a fornicator, or an usurer, or one who has sold himself to the devil, or a spiteful denouncer, [...] do not stay at dinner with any of them'

c. oare moșul cū nepotul săva doi frațî

either uncle.DEF with nephew.DEF or two brothers

a se împreuna cu mîtușe micî

$\mathrm{A}_{\text {INF }}$ CL.REFL.ACC.3PL pair.INF with aunt little

și cu nepoata-i (Prav.1581, 266 ${ }^{\mathrm{v}}$ )

and with niece $=$ CL.DAT.3sG

'neither an uncle with his nephew nor two brothers shall be bound by marriage to an aunt with her niece'

The variation of the connectives occurs frequently within the same text, so that a preference for a certain connective cannot be identified without a rigorous statistics.

An asymmetrical syntactic pattern including veri contains, as first element, a propositional structure $(7 \mathrm{a}-\mathrm{f})$, with the verb in a mood or tense that is marked as irrealis, possible, the main features of disjunction in natural languages (Zafiu, 2012): subjunctive ( $7 a-c)$, conditional ( $7 d)$, future $(7 \mathrm{e}, \mathrm{f})$, followed by a set of alternatives lexicalized as elliptical structures, that retains only the information level relevant elements [the subject predicative complement in (7a,b,c,e,f), adjectival modifiers in (7d)]:

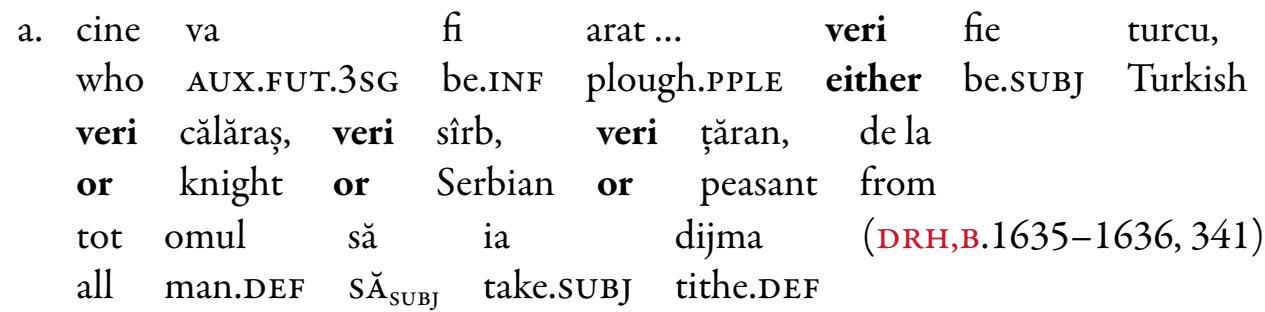

'Anyone who would have ploughed ... either a Turk, or a knight, or a Serbian, or a peasant, all of them must pay the tithe'

b. veri fie muiare, veri fată $(s ̦ T .1652,277)$

either be.suBJ woman or girl

'be it either a woman or a girl'

c. Iară de va fi nevoie, să fie pruncul spre moarte

and if AUX.FUT.3sg be.INF need to be baby.DEF to death

să-1 boteadze ori în ce ceas vor

S $\breve{A}_{\text {SUBJ }}=$ CL.ACC.3SG baptise.SUBJ any in what moment AUX.FUT.3PL

chema preotul, veri fie noapte, veri dzuo (șT.1652,28)

call.INF priest.DEF either be.SUBJ night or day

'and if necessary, should the baby be dying, it must be baptised at any moment, the priest will be able to come, be it day or night'

d. să-l caute, să-l prinză,

$S \breve{A}_{\text {SUBJ }}=C L . A C C .3 \mathrm{sG} \quad$ search.SUBJ $\quad \breve{A}_{\text {SUBJ }}=C L . A C C .3 s G \quad$ catch.SUBJ

veri să 1 -ar afla în țigănie

either if CL.ACC.3SG=AUX.COND.3sG find in Gypsy servitude

domnească, veri boerească, veri călugărească (DRH,B.1635-1636,348)

lordly or manory or monastic

'to search for him and fetch him, in any kind of Gypsy servitude they were to find him, be it a ruler's one, or a nobleman's, or a monastery's'

e. veri va fi mare, veri mic,

either AUX.FUT.3SG be.INF big or small 


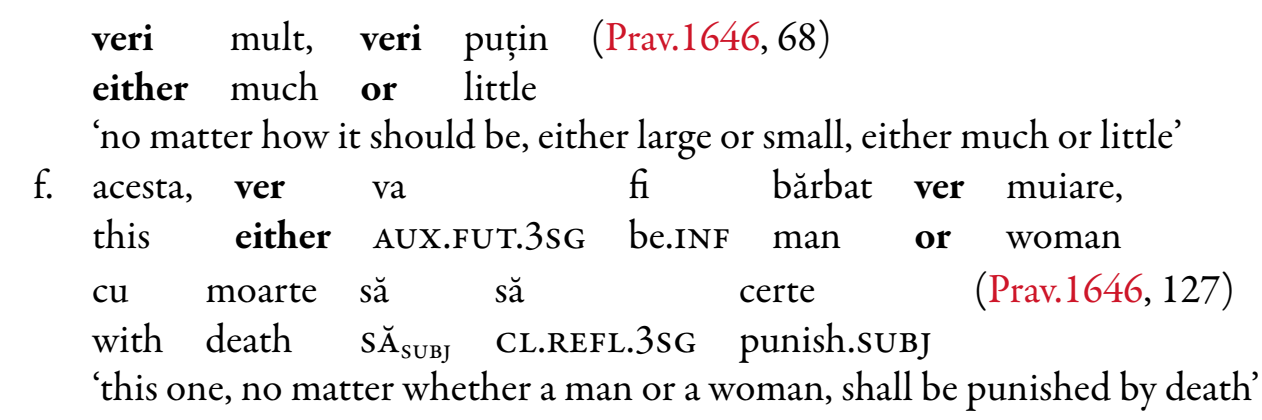

The subjunctive $f i e$ 'be' in $(7 \mathrm{a}, \mathrm{b})$, which displays verbal value in these contexs, proved by the patterns $(7 \mathrm{~b}-$ d), gradually develops as the main disjunctive connective, while veri fades away.

Within the symmetric disjunctive correlative pattern, veri can occur with different syntactic phrases: noun phrases (8a), adjectival phrases $(8 \mathrm{~b}, \mathrm{c})$, prepositional phrases $(8 \mathrm{~d}-\mathrm{g})$, adverbial phrases $(8 \mathrm{~h})$, or sentence structures $(8 \mathrm{i})$ :

(8) a. Oricare mirean, veri bărbat, veri muiare, dacă va mearge any layman either man or woman if AUX.FUT.3sG go.INF la beserică fie la ce slujbă, veri vecernie, veri la to church be.SuBJ to what service either evensong or to itros, veri la ceasuri, veri la Svînta Liturghie (șT.1652, 104) morning service or to breviaries or to Holy Liturgy 'any layman, either a man or a woman, should go to the church, to any service, either evensong, or morning service, or the breviaries, or the Holy Liturgy'

b. carele va găsi pre marginea unii ape mari, who AUX.FUT.3SG find.INF on shore of water.gen large.F.SG.GEN fie ce lucru, ver mare, ver mic, carile va be.SUBJ what thing either big or small who AUX.FUT.3sG fi aruncat apa ca o plavie (Prav.1646, 69) be.INF throw.PpLE water like a small island 'he who will find on a water shore anything, either large or small, that shall be floating when thrown by the water'

c. veri tînăr veri bătrîn $i \quad$ să either young or old CL.DAT.3SG CL.REFL.ACC va tăia capul (Prav.1646, 163) shall cut head 'he will have his head cut off, should he be either young or old'

d. preotul de va fi oprit de liturghie, priest.DEF if shall be cut away from liturgy veri cu vină, veri fără de vină $($ șT.1652, 130) either with guilt or without guilt 'any priest which should be cut away from the liturgy, either with guilt or without guilt'

e. cine o va rușina veri cu voe who CL.ACC.F.3sG shall dishonour either with will veri fără voia ei (Prav.1646, 136) or without will her 'who will dishonour her, either by her will or against her will'

f. să picnească dencătro i va fi voia, to hit from CL.DAT.3sg shall be will veri în mijloc, veri de lături (DRH,B.1646, XXXI, 143) either in middle or aside 
'to hit from wherever he wishes, either in the middle or aside'

g. Iar cine se va ispiti a sparge această tocmeală a

and who shall dare to break this agreement of

noastră, veri den feciorii noștri, veri den rudele

our either of sons our or of relatives

noastre, acela să fie proclet (DRH,B.1635,26)

our that to be damned

'And anyone who will dare to break our agreement, either among our sons, or among our relatives, that one shall be damned'

h. cela ce va găsi ceva mărgînd pă drum,

that who shall find something walking on road

fie ce va fi, veri mult, veri puțin (Prav.1646, 68)

be what shall be either much or little

'that one who will find something while walking on the road, whatever it will be, either much or little'

i. Iară de va fi neștine de 30 de ai veri

and if shall be anyone of 30 of years either

aibă feciori, veri nu aibă, să nu se cuminece

have sons or NEG have tp not receive Eucharist

(șT.1652, 249)

'and anyone who shall be 30 years of age, either with heirs, or without heirs, that one shall not receive the Eucharist'

The corpus of old Romanian texts displays a few occurrences of disjunctive să veri 'either' (written either with or without a blank space between the elements $s \breve{a}$ and veri):

(9)
a. Derept aceaia plecați-vă
for
that
submit=yourselves to all
omenească
pentru
Domnul: săveri lư̆
craŭu ca ūnǔ̆
human
for God
either LUI.DAT king
like
săveri deregătorilor, ca trimişilor de la dinsu. (NT.1648, 183²)
or governors.DEF.DAT like deputies.DAT from him
'Therefore, you must submit to any human power for God: either to the king as a superior, or to the governors, as his deputies.'
deregătoria
$\begin{array}{lllllllll}\text { b. oricine va indrăzni } & \text { pentru treaba lui de va lua ceva, } \\ \text { whoever shall dare } & \text { for } & \text { need his if shall take something }\end{array}$

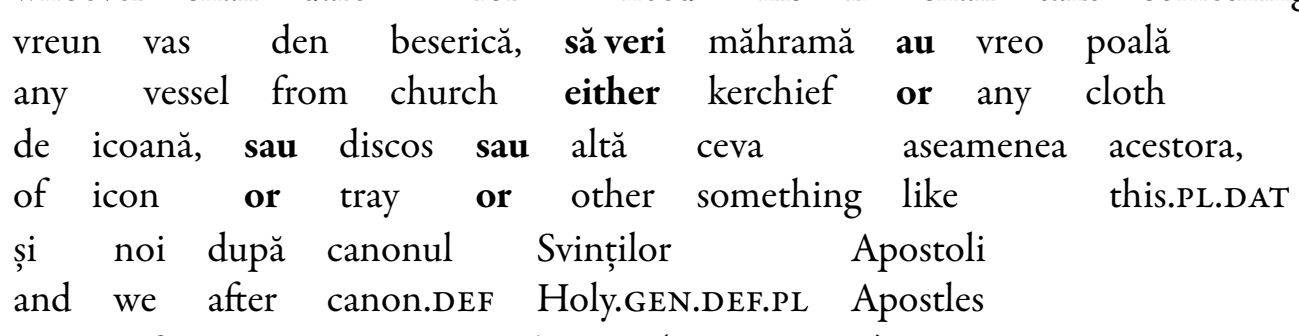
punem afurisenie asupra lor (șT.1652,161)
anathemize.PRES.1PL on them
whoever will dare to take anything for his need, any vessel from the church, either kerchief or any cloth for the icons, or tray or anything like that, we anathematize them following the canon of the Holy Apostles'

Formally, să veri is created analogically to săva (să followed by the third person, va, from the paradigm of a vrea 'to want'), which occurs more frequently as a disjunctive (Zamfir \& Dinică, 2009). 
In (9a), să veri is repeated as a part of a correlative, although there are vacillations regarding the spelling, while in (9b) it introduces only one element of the set (să veri măhramă 'either veil') and it is correlated to sau 'or'.

\subsubsection{Formative element of the concessive conjunction}

Să veri că 'although', analogical to săva (i) că (discussed in Zamfir \& Dinică, 2009), is attested, within the corpus we investigated, only in NT.1648:

(10) a. Și pentru că nu le putea asămăna că le părea că grăiaște împrotivâ ūna alțiiia iaarâ ēi lepăda cartea luŭ Ĭacov din cărțile sfinte. Să veri cằ bine să tocmescă numaĭ să socotiți bine, că nu grăesc amăndoi di ūn feal de credințâ și de ūn feal de îndereptătură. (NT.1648, 174 ${ }^{\mathrm{r}}$ )

'And because they could not consider them alike, being under the impression that these books were one against the another, they rejected the book of Jacob from the holy books. Although they are well matched only if you consider them carefully, because they don't speak about the same kind of faith and about the same kind of atonement.'

b. cum s-au ferit și èl de n-au luat platâ, să ver că-1̌ ēra slobod (NT.1648, 223 ${ }^{\text {r }}$ ) 'how he also took care and didn't accept the pay, although it was allowed to him'

c. Ĭarâ deaca veniiu în Trōada a propovedui Evangheliia lư̆ Hristos, să ver că- mī èra mie poarta deșchisâ pren Domnul, nu avuiu răpao sufletuluı̆ mieu. (NT.1648, 241 ${ }^{\mathrm{v}}$ ) 'and when I came to Troas to preach Christ's gospel, although the gate was open in front of me by God, I could not get the rest of my soul.'

The number of occurrences of să veri că in old Romanian is not significant, but this connective created analogically is highly relevant for the multiple functions of veri in old texts.

\subsection{Marker in the structure of indefinite pronouns}

The evolution of some forms in the paradigm of the verb a vrea 'to want' to disjunctive-concessive conjunctions and indefinite markers is typologically identifiable (Haspelmath, 1997). In Romanian, the available old texts do not preserve traces of the grammaticalization process, which had already been accomplished at the moment of the oldest Romanian texts, but examples like (11) instantiate a possible path of use from disjunctive correlative connective to indefinite marker:

(11) nici un datornic, veri turcu, veri neguțătoriu, verice feliu de om va fi, nimenilea treabă cu Radul logofătul să n-aibă, nice cu zestrele jupînesei lui, veri sat, veri țigani, veri dobitoc, veri ce va avea Radul logofătul (DRH,B.1636, XXV, 470)

'no creditor, either Turk, or merchant, or whatever kind of man should be, nobody should bother either Radu the Chancellor, or his lady's dowry, either village, or gypsies, or animals, or whatever Radu the Chancellor might own'

In the specific pattern in which the disjunctive correlative veri occurs to enumerate the instances of reifying the general term (zestrelejupanesei 'the dowries of the lady' in example 11) and its instances of actualization (sat 'village', tigani 'gypsies', dobitoc 'animal'), the last element is a relative clause (ce va avea Radul logofatul). In this type of structures, the connective is attached to the relative element as a marker and produces series of indefinite pronouns that will occur independently of the primary, disjunctive contexts they arouse from.

The texts offer many contexts where the indefinite marker exhibits relative fusion in various stages:

a. Iar de va vrea cineva din rudele mele, veri
and if shall want someone from relatives my want.PREs.2sG
cine va f, să ia acești țigani (DRH,B.1635, XXV, 75)
who shall be to take these gypsies
and if any of my relatives, whoever it might be, wants to take these gypsies'


b. să aibă a luoare dijmă de pre toată ocina sventei monastiri

to have $A_{\mathrm{INF}}$ take tithe from all land holy.DEF.geN monastery

și de la cîmpu... și de la tot omul, care se

and from field and from all man.DEF.SG who CL.REFL.ACC

va hrăni pre ocina mănăstirii, veri

shall feed from land monastery.DEF.GEN want.PREs.2sG

cu ce se vor hrăni (DRH,B.1635, XXV, 99)

with what CL.REFL.ACC shall feed

'to be allowed to take tithe from the whole land of the monastery and from the fields, and from everybody who gets his sustenance from the land of the monastery, no matter what it is'

c. am vîndut 3 pogoane de țelină au

AUX.PERF.1SG sell.PPLE 3 acres of land either

la Gruiu, au la Sperlea, veri unde le

to Gruiu or to Sperlea want.PREs.2sG where CL.DAT.3PL

va plăcea dumnealor (DRH,B.1646, XXXI, 273)

shall like they.DAT

'I sold 3 acres of land either to Gruiu, or to Sperlea, wherever they will choose to have them'

d. viile de la Copăcel $\mathrm{cu}$ rumânii și $\mathrm{cu}$ tot venitul,

vineyards from Copăcel with bondsmen and with all income

vericît să va alege (DRH,B.1635, XXV, 83)

want.PRES.2SG.how CL.REFL.ACC shall choose

'the vineyards from Copăcel with the bondsmen and all the income, however it will be'

e. partea de moșie a tătîne-nostru vericîtă

part of land $\mathrm{A}_{\mathrm{GEN}}$ father=our want.PRES.2sG.how

să va afla în sat (DRH,B.1635, XXV, 93)

CL.REFL.ACC shall be in village

'the part of land that belongs to our father, however it were inside the village'

f. carii deîntru feciorii noștri, au deîntru rudeniile nostre,

who of sons our or of relatives our

au deîntr-alt neam se va ispiti veri cînd

or from=other family CL.REFL.ACC shall dare want.PREs.2sG when

a sparge şi a strica această tocmeală (DRH,B.1635, XXV, 97)

to break and to ruin this agreement

'anyone among our sons or among our relatives, or any other family will dare at any time to break this agreement'

g. de să vor și ridica vericînd (DRH,B.1645, XXX, 323)

if CL.REFL.ACC shall too raise want.PRES.2SG.when

'even if they raise at any moment'

The example (12), which presents a morphological instance in-between a verb, a disjunctive conjunction and an indefinite marker, is relevant for the incomplete fusion, for the incomplete grammaticalization process, and for the multiple functions of veri. 


\section{Conclusions}

In this article we have illustrated the types of occurrences and the directions of evolution of a very longevous (attested until the $19^{\text {th }}$ century) etymological form from the paradigm of a vrea 'to want'. With a verbal value, veri is used with high frequency, but early competed by vei, the subsequent phonetic outcome. As a disjunctive-concessive connector and as an indefinite marker, veri is more frequent than ori in early texts. It is specific to patterns in law codices and it is widely competed by other connectors in the epoch. Its persistence over three centuries and elimination from present-day Romanian are evidence of a universal cyclical change (van Gelderen, 2016). The polifunctional feature of veri is specific to other elements in old Romanian (see Vasilescu, 2017, in this volume).

\section{Bibliography}

\section{A. Corpus}

св.1559-60 = Codicele Bratul, ed. Al. Gafton, Iași, 2003, [online].

$\mathrm{CC}^{2} .1581$ = Coresi, Evanghelie cu învățătură, în Carte cu invvățătură (1581), vol. I, Textul, ed. S. Pușcariu \& Al. Procopovici,

Atelierele Grafice Socec, București, 1914.

Ст.1560-1 = Coresi, Tetraevanghel, în Tetraevanghelul tipărit de Coresi, Braşov 1560-1561, comparat cu Evangheliarul lui

Radu de la Mănicești. 1574, ed. Fl. Dimitrescu, Editura Academiei, București, 1963.

DRH,B = Documenta Romania Historica. B. Țara Românească, Editura Academiei Române, București, 1974: vol. XXIV (1633-

4); 1985: vol XXV (1935-1936), 1998: vol. XXXI (1645).

NT.1648 = Noul Testament, Editura Reîntregirea, Alba Iulia, 1998.

PH.1500-10 = Psaltirea Hurmuzaki, ed. I. Gheție \& M. Teodorescu, Editura Academiei Române, București, 2005.

po.1582 = Palia de la Orăștie, ed. V. Pamfil, Editura Academiei, București, 1968.

Prav.1581 = Pravila ritorului Lucaci, 1581, ed. I. Rizescu, Editura Academiei, București, 1971.

Prav.1646 = Carte românească de invățătură, 1646, ed. A. Rădulescu, Editura Academiei, București, 1961.

Prav.1652 = Îndreptarea legii, 1652, ed. A. Rădulescu, Editura Academiei, București, 1962.

Ps.1573-8 = Psaltirea Scheiană comparată cu celelalte psaltiri din secolele al XVI-lea și al XVII-lea, ed. I.-A. Candrea, Socec,

București, 1916; Psaltirea Scheiană, ed. I. Bianu, Carol Göbl, București, 1889.

șT.1652 = Şeapte taine a besearecii, Iași, 1644, ed. I. Mazilu, Editura Universităţii „Alexandru Ioan Cuza”, Iaşi, 2012.

\section{B. References}

Croitor, B. (2016). Coordination and coordinating conjunctions, în Pană Dindelegan, G. (ed.), The Syntax of Old Romanian, Oxford University Press, Oxford, Crossref.

Densusianu, O. (1997). Historie de la langue roumaine, I. Les origines, II. Le seizième siècle, Ediție critică și note de V. Rusu, Prefață de B. Cazacu, Editura „Grai și Suflet - Cultura Națională”, București.

Ernout, A. \& Meillet, A. (1959). Dictionnaire Étymologique de la Langue Latine, Klincksieck, Paris.

Frâncu, C. (2009). Gramatica limbii române vechi (1521-1570), Casa Editorială Demiurg, Iași.

Haspelmath, M. (1997). Indefinite Pronouns, Clarendon Press, Oxford.

Sandfeld, Kr. (1930). Linguistique balkanique. Problèmes et résultats, Librairie Ancienne Honoré Champion, Paris.

van Gelderen, E. (ed.) (2016). Cyclical Change Continued, John Benjamins Publishing Company, Amsterdam, Crossref.

Vasilescu, A. (2017). The descendants of Lat. ipse in Romanian, in "Diacronia", 6, Sept. 30, art. A87, Crossref.

Zafiu, R. (2012). Conectorii disjunctivi din perspectivă semantico-pragmatică: ipoteze asupra proceselor de gramaticalizare, in "Limba română", vol. LXI, nr. 3, p. 417-428.

Zamfir, D.-M. (2005). Morfologia verbului in dacoromâna veche (secolele al XVI-lea - al XVII-lea), vol. I, Editura Academiei Române, București.

Zamfir, D.-M. (2007). Morfologia verbului in dacoromâna veche (secolele al XVI-lea - al XVII-lea), vol. II, Editura Academiei Române, București.

Zamfir, D.-M. \& Dinică, A. (2009). Quelques cas de grammaticalisation des formes flexionnelles du verb a vrea «vouloir» en vieux daco-roumain: les conjonctions et locutions conjonctionnelles disjonctives et concessives (să) veri (că) «ou; soit; soit même; bien que», săva(i) (că) «idem», presented at the colloquium Grammaticalization and Pragmaticalization in Romanian, University of Bucharest, October 3-4, 2008. 